\title{
Design, synthesis, preliminary pharmacological evaluation, molecular docking and ADME studies of some new pyrazoline, isoxazoline and pyrimidine derivatives bearing nabumetone moiety targeting cyclooxygenase enzyme
}

Omar A. Yousif,a* Monther F. Mahdi, ${ }^{b}$ and Ayad M. R. Raaufc

aDepartment of Pharmacy, Baghdad College of Medical Science, Baghdad, Iraq.

bDepartment of Pharmacy, Ashur University College, Baghdad, Iraq.

'Department of Pharmaceutical Chemistry, College of Pharmacy, University of Mustansiriyah, Baghdad, Iraq.

*Correspondence to Omar A. Yousif (email:omar.auday@yahoo.com).

(Submitted: 07 October 2018 - Revised version received: 25 October 2018 - Accepted: 01 December 2018 - Published online: 26 February 2019)

Objective To synthesize and initial pharmacological assessment of new analogues of nabumetone by studying their interactions with COX-1 and COX-2 by docking and to determine some relationships between their structures and biological activity. Incorporating of three pharmacophoric heterocyclic ring systems into the nabumetone moiety to increase the selectivity toward COX-2 and reduce side effects. Comparing the In silico results with In vivo results by using egg white to induce acute inflammation.

Methods A series of pyrazolines, oxazolines, and pyrimidines bearing nabumetone moiety have been designed, synthesized, and evaluated as a potential COX-2 inhibitors. These new compounds were evaluated for their in vivo anti-inflammatory activity and in silico COX-2 selectivity through molecular docking via genetic optimization for ligand docking Suite v. 5.6.2.

Results All tested compounds in molecular docking exhibited significant activities compared with diclofenac, naproxen, and 6MNA as reference drugs due to their hydrogen bonding interaction with key amino acids in COX isozymes Arg120, Tyr355, and Ser530. The results are compatible with their in vivo acute anti-inflammatory study for tested compounds. The ADME results showed that all synthesized compounds absorbed from GIT while, only compounds 3, 2a, 2c, and 3a-3c fulfilled the Lipinski rule.

Conclusion The synthesis of the designed compounds has been successfully achieved, the anti-inflammatory assessment of the final products indicates that the incorporation of pyrazoline, isoxazoline, and pyrimidine pharmacophore into nabumetone improved its antiinflammatory action, docking studies showed a perfect agreement with In vivo study of compounds (1c, 2a, 2b, 3b and 3c), the Preliminary study of anti-inflammatory activity showed that compound (1c and $3 \mathrm{c}$ ) have significantly more anti-inflammatory outcome than all compounds.

Keywords nabumetone, docking, ADME, GOLD, Lipinski rule

Graphical Abstract

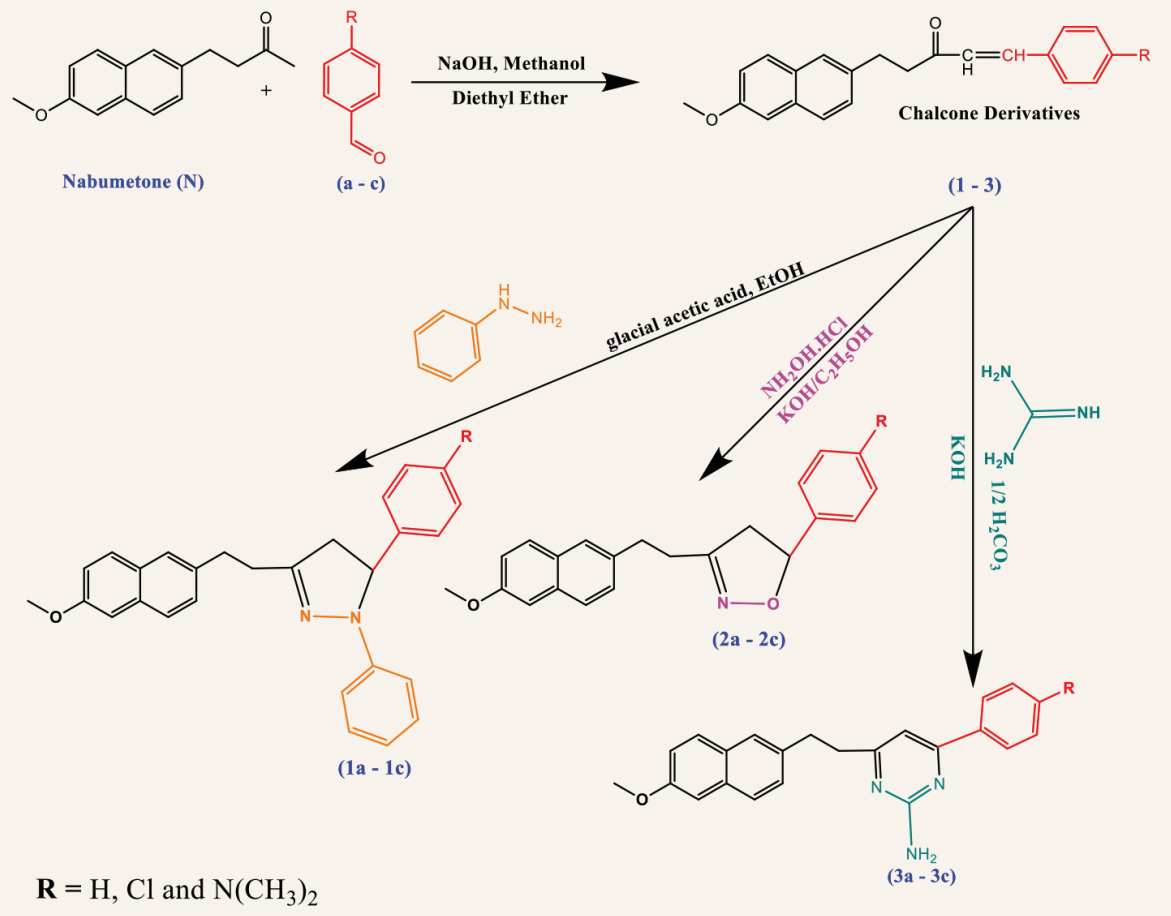




\section{Introduction}

Non-steroidal anti-inflammatory drugs (NSAIDs) are the most prescribed therapeutic drugs for the treatment of pain and inflammation. ${ }^{1}$ One of the primary strategies to develop novel drugs is the modification of well-known non-selective NSAIDs. ${ }^{2,3}$ Some studies have shown that the derivatization of the carboxylate function of representative NSAIDs could increase anti-inflammatory activity while reducing gastrointestinal side effects. ${ }^{4-7}$ The cyclooxygenase (COX) binding site is a hydrophobic channel. The charged residues in the two COXs are Glu524 and Arg120. X-ray data show that Arg120, located midway down the COX channel, interacts with the carboxylic group of the AA and classical NSAIDs in COX $-1 .{ }^{8}$ First, the substitution of Ile523 in COX-1 with the less bulky Val523 in COX-2 allows access to an additional polar side pocket and increases the volume of the COX active site. Such enhancement is also due to the substitution of Ile434 in COX-1 with Val in COX-2 that allows the Phe518 to move back. ${ }^{9}$ The existence of this side pocket in COX-2 enable additional interactions with amino acids such as Arg513, replaced by a His in COX-1. This change would be another contribution to COX-2 specificity. ${ }^{10}$ Second, the conserved Leu384, situated at the top of the channel, is oriented differently in the COX-1 and COX-2 because of the effects of a residue at position 503. In COX-1, the presence of phenylalanine forces the Leu384 side chain to lie into the active site. In COX-2, a smaller leucine at this position allows the Leu384 side chain to move away from the active site and generates an accessible space in the apex of the COX-2 binding site. ${ }^{11}$

The COX-2 is similar to COX-1 enzyme except for the replacement of the three amino acids that mentioned above that made the polar hydrophilic side pocket of COX-2 active site bigger than the COX-1 active site, lead to large molecules could not fit into the COX-1 active site but still have the ability to bind with COX-2 enzyme. ${ }^{12,13}$ The COX-2 active site consists of 22 amino acids divided into three cavities: aromatic region (cavity $\mathrm{A}$ ), aliphatic region (cavity $\mathrm{B}$ ), selective region (cavity C) (Fig. 1)<smiles>COc1ccc2cc(CCC(C)=O)ccc2c1</smiles>

(1)

(2)<smiles>O=C(C=Cc1ccccc1)c1ccccc1</smiles>

(3)

Selective COX-2 inhibitors give a beautiful example of bioisosterism of heterocycles. Pyrazolines, pyrimidines, and isoxazolines are good bioisosteres of each other. ${ }^{14}$ Nabumetone (1) [4-(6-methoxy-2-naphthalenyl)-2-butanone] is a nonacidic broad-spectrum anti-inflammatory, antipyretic, and analgesic agent. This drug was later licensed to Bencard, Fujisawa, Uriach, and Ambelette. Its activity is greater than that of aspirin and comparable to indomethacin and naproxen. ${ }^{15}$ The active metabolite of nabumetone 6-methoxy-2-naphthylacetic acid (6MNA) (2) is responsible for the therapeutic effect. Nabumetone is a weak COX-2 inhibitor and it has less nephrotoxicity than indomethacin. ${ }^{16}$

Chalcones (3) belong to important classes of natural products, distributed in spices, vegetables, fruits, tea, and soybased foodstuff. Chalcones considered is one of the most important classes due to their interesting pharmacological activities. ${ }^{17}$ Twelve replaceable hydrogen atoms in chalcone structure makes the chalcone magical in drug design field due to the generation of a large number of derivatives and various promising biological molecules, e.g., anti-inflammatory, ${ }^{18}$ antigout, ${ }^{19}$ antihistaminic, ${ }^{20}$ antioxidant, ${ }^{21}$ antiobesity, ${ }^{22}$ antiprotozoal, ${ }^{23}$ hypnotic, ${ }^{24}$ antispasmodic, ${ }^{25}$ etc.

Pyrazoline derivatives were found to have potential antipyretic, analgesic, tranquilizing, muscle relaxant, psycho analeptic, antiepileptic, antidepressant, anti-inflammatory, insecticidal, antimicrobial, and antihypotensive activities. Their derivatives were also found to exhibit cytotoxic activity, inhibitory activity of platelet aggregation, herbicidal activity, and cannabinoid CB1-receptor modulators. ${ }^{26}$

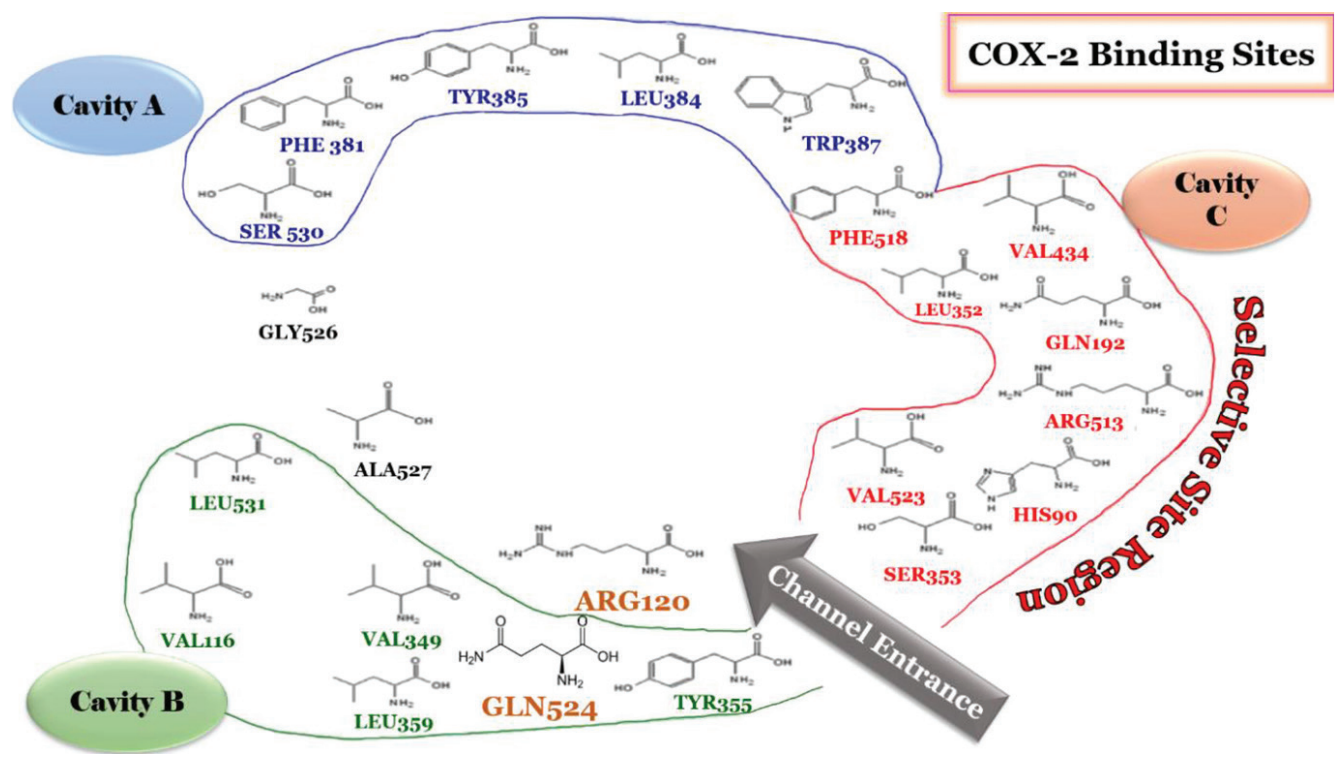

Fig. 1 COX-2 receptor active site and its amino acids profile. 
The oxazoline ring is an important pharmacophore of bioactive natural products and pharmaceuticals. The oxazoline ring presents an interesting structure on which to build a wide variety of compounds having antioxidant, antimicrobial, anti-inflammatory, antimalarial, antitumor, antiviral, antitubercular, antipyretic, and central nerves system stimulant activities. ${ }^{27}$

Pyrimidine derivatives are known to be biologically active compounds and substituted pyrimidines have shown wide range of biological activities such as antitubercular, ${ }^{28-30}$ antibacterial, ${ }^{31-33}$ antioxidant, ${ }^{31}$ anti-inflammatory activity. ${ }^{34}$

\section{Materials and Methods}

\section{General}

All reagents and anhydrous solvents were of analar type and generally used as received from the commercial suppliers (Merck, Germany, Reidel-De Haen, Germany, Sigma-Aldrich, Germany and BDH, England). Nabumetone was supplied by the Shanghai Renyoung Company, China. Melting points were determined by capillary method on Bamstead/Electrothermal 9100 an Electric melting point apparatus (England) and ascending thin layer chromatography (TLC) to check the purity and progress of reactions was run on DC-Kartan SI alumina $0.2 \mathrm{~mm}$ plates. The identification of compounds was done using a UV IR spectrum were recorded on a FTIR-spectrophotometer FT-IR-6100 TypeA as KBr disks. ${ }^{1} \mathrm{H}-\mathrm{NMR}$ determined by $\mathrm{H}-\mathrm{NMR}$ device $500 \mathrm{MHz}$ Benchtop (Magritek)

General procedure for the synthesis of chalcone derivatives, 1-(4-aryl)-5-(6-methoxynaphthalen-2-yl) pent-1-en-3-one (1-3): $0.088 \mathrm{~g}, 2.2 \mathrm{mmol}$ of $\mathrm{NaOH}$ dissolved in 5:2.5 methanol 99\%:D.W., and stirred for $15 \mathrm{~min}$. In a beaker $0.500 \mathrm{~g}, 2.2 \mathrm{mmol}$ of nabumetone dissolved in 5:10 solvent system diethyl ether:methanol, stirring for 10 min until the compound will completely dissolve, then benzaldehydes derivatives (a-c) $2.2 \mathrm{mmol}$ was added, followed by the addition of $\mathrm{NaOH}$ solution. The mixture was exposed to an ultrasonic generator in a water bath at $35^{\circ} \mathrm{C}$ for 25 min turbidity appeared in the mixture, which was then neutralized with $2 \mathrm{~N} \mathrm{HCl}$. The yellow precipitate was formed, filtered with cold water and recrystallized by methanol. ${ }^{35,36}$

General procedure for the synthesis of pyrazoline derivatives, 3-(2-(6-methoxynaphthalen-2-yl) ethyl)-1-phenyl-5(4-aryl)-4,5-dihydro-1H-pyrazole derivatives (1a-1c): A mixture of chalcone derivatives $(\mathbf{1 a}-\mathbf{1 c})(1.0 \mathrm{mmol})$ and phenylhydrazine $(0.27 \mathrm{~mL}, 2.8 \mathrm{mmol})$ in $20 \mathrm{~mL}$ of absolute ethanol was refluxed, after 15 min two drops of catalytic glacial acetic acid was added, and the contents allowed getting reflux for $24 \mathrm{~h}$. The reaction time was considered by performing TLC to obtain single spot $(20 \mathrm{~mL})$. Cold water was added to the mixture to precipitate out the product. The product was filtered and washed twice with cold water, and finally dried and recrystallized from hot ethanol. ${ }^{37}$

General procedure for the synthesis of isoxazoline derivatives, 3-(2-(6methoxy-naphthalen-2-yl)ethyl)-5-(4-aryl)-4,5-dihydroisoxazole derivatives $(\mathbf{2 a}-\mathbf{2 c})$ : Chalcone derivatives $(\mathbf{1 a}-1 \mathrm{c})(1.0 \mathrm{mmol})$ and hydroxylamine hydrochloride $(0.069 \mathrm{~g}$, $1.0 \mathrm{mmol}$ ) were taken in $10 \mathrm{~mL}$ ethanol. About $50 \%$ ethanolic potassium hydroxide solution $(2 \mathrm{~mL})$ was added dropwise to the reaction mixture with stirring at room temperature. The reaction mixture was refluxed for 12-20 h. After completion of the reaction, the mixture was cooled and acidified with glacial acetic acid. The reaction time was considered by performing TLC to obtain single spot. The excess solvent was removed under reduced pressure and concentrate was poured into ice water. The precipitate was filtered, washed with water, dried and recrystallized from hot ethanol. ${ }^{38}$

General procedure for the synthesis of pyrimidine derivatives, 4-(4-aryl)-6-(2-(6-methoxynaphthalen-2-yl) ethyl) pyrimidin-2-amine (3a-3c): Chalcone derivatives (1-3) (1 mmol) were dissolved in ethanol $(25 \mathrm{~mL})$, guanidine carbonate $(0.180 \mathrm{~g}, 1 \mathrm{mmol})$, and a solution of $20 \% \mathrm{KOH}(5 \mathrm{~mL})$ were added and refluxed for $16 \mathrm{~h}$. The reaction time was considered by performing TLC to obtain single spot. The reaction mixture was cooled, poured into crushed ice. The product obtained was filtered, washed with water, dried and recrystallized from ethanol..$^{39}$

5-(6-Methoxynaphthalen-2-yl)-1-phenylpent-1-en-3-one (1): Yellow crystals ( $82 \%$ yield); mp $116-117^{\circ} \mathrm{C}$; IR (KBr) $v$ $\left(\mathrm{cm}^{-1}\right)$ : 1238.77 (C-O-CH$), 1553.69$ (aromatic), 1702.15 $(\mathrm{C}=\mathrm{O}) ;{ }^{1} \mathrm{H}-\mathrm{NMR}$ (DMSO- $\left.d, 500 \mathrm{MHz}\right): \delta 2.79\left(\mathrm{t}, 2 \mathrm{H}, \mathrm{CH}_{2}-\right.$ $\left.\mathrm{CH}_{2}\right), \delta 2.85\left(\mathrm{t}, 2 \mathrm{H}, \mathrm{CH}_{2}-\mathrm{CH}_{2}\right), \delta 3.88\left(\mathrm{~s}, 3 \mathrm{H}, \mathrm{O}-\mathrm{CH}_{3}\right), \delta 6.80$ $(\mathrm{d}, 1 \mathrm{H}, \mathrm{CH}=\mathrm{CH}), \delta 7.08(\mathrm{~d}, 1 \mathrm{H}, \mathrm{CH}=\mathrm{CH}), \delta 7.6-7.83(\mathrm{~m}, 11 \mathrm{H}$, aromatic $\mathrm{H})$.

1-(4-Chlorophenyl)-5-(6-methoxynaphthalen-2-yl)pent-1en-3-one (2): White powder (89\% yield); mp $129-131^{\circ} \mathrm{C}$; IR $(\mathrm{KBr}) v\left(\mathrm{~cm}^{-1}\right): 1268.44\left(\mathrm{C}-\mathrm{O}-\mathrm{CH}_{3}\right), 1588.01$ (aromatic), $1691.62(\mathrm{C}=\mathrm{O}) ;{ }^{1} \mathrm{H}-\mathrm{NMR}$ (DMSO- $\left.d_{6}, 500 \mathrm{MHz}\right): \delta 2.7(\mathrm{t}, 2 \mathrm{H}$, $\left.\mathrm{CH}_{2}-\mathrm{CH}_{2}\right), \delta 2.8\left(\mathrm{t}, 2 \mathrm{H}, \mathrm{CH}_{2}-\mathrm{CH}_{2}\right), \delta 3.89\left(\mathrm{~s}, 3 \mathrm{H}, \mathrm{O}-\mathrm{CH}_{3}\right), \delta$ $6.64(\mathrm{~d}, 1 \mathrm{H}, \mathrm{CH}=\mathrm{CH}), \delta 7.50(\mathrm{~d}, 1 \mathrm{H}, \mathrm{CH}=\mathrm{CH}), \delta 7.07-7.84$ $(\mathrm{m}, 10 \mathrm{H}$, aromatic $\mathrm{H})$.

1-(4-(Dimethylamino)phenyl)-5-(6-methoxynaphthalen-2-yl)pent-1-en-3-one (3): Yellow buff powder (71\% yield); $\mathrm{mp} 135-137^{\circ} \mathrm{C}$; IR $(\mathrm{KBr}) v\left(\mathrm{~cm}^{-1}\right): 1151.11\left(\mathrm{~N}-\mathrm{CH}_{3}\right), 1234.58$ (C-O-CH ${ }_{3}$ ), 1598.41 (aromatic), $1686.41(\mathrm{C}=\mathrm{O}) ;{ }^{1} \mathrm{H}-\mathrm{NMR}$ (DMSO- $\left.d_{6}, 500 \mathrm{MHz}\right): \delta 2.7\left(\mathrm{t}, 2 \underline{\mathrm{H}}, \mathrm{CH}_{2}-\mathrm{CH}_{2}\right), \delta 2.8(\mathrm{t}, 2 \mathrm{H}$, $\left.\mathrm{CH}_{2}-\mathrm{CH}_{2}\right), \delta 3.01\left(\mathrm{~s}, 6 \mathrm{H}, \mathrm{N}\left(\mathrm{CH}_{3}\right)_{2}\right), \delta 3.88\left(\mathrm{~s}, 3 \mathrm{H}, \mathrm{O}-\mathrm{CH}_{3}\right)$, $\delta 6.62(\mathrm{~d}, 1 \mathrm{H}, \mathrm{CH}=\mathrm{CH}), \delta 7.08(\mathrm{~d}, 1 \mathrm{H}, \mathrm{CH}=\mathrm{C} \underline{\mathrm{H}}), \delta 7.23-7.80$ $(\mathrm{m}, 10 \mathrm{H}$, aromatic $\mathrm{H})$.

3-(2-(6-Methoxynaphthalen-2-yl)ethyl)-1,5-diphenyl-4,5dihydro-1H-pyrazole (1a): Yellow crystals (91\% yield); mp $168-170^{\circ} \mathrm{C}$; IR $(\mathrm{KBr}) v\left(\mathrm{~cm}^{-1}\right): 1234.62(\mathrm{C}-\mathrm{N}$ of diazole), $1259.89\left(\mathrm{C}-\mathrm{O}-\mathrm{CH}_{3}\right), 1505.26$ (aromatic), $1619.63(\mathrm{C}=\mathrm{N}$ of diazole); ${ }^{1} \mathrm{H}-\mathrm{NMR}$ (DMSO- $\left.d, 500 \mathrm{MHz}\right): \delta 2.65(\mathrm{t}, 2 \mathrm{H}$, $\mathrm{CH}_{2} \underline{\mathrm{CH}}_{2}$ ), $\delta 2.8$ (t, $\left.2 \mathrm{H}, \mathrm{CH}_{2} \mathrm{CH}_{2}\right), \delta 3.01$ (d, $2 \mathrm{H}$, diazole $\mathrm{CH}_{2}$ ), $\delta 3.89\left(\mathrm{~s}, 3 \mathrm{H}, \mathrm{O}-\mathrm{CH}_{3}\right), \delta 5.25(\mathrm{t}, 1 \mathrm{H}$, diazole $\mathrm{CH}), \delta 6.97-7.81$ $(\mathrm{m}, 16 \mathrm{H}$, aromatic $\mathrm{H})$.

5-(4-Chlorophenyl)-3-(2-(6-methoxynaphthalen-2-yl) ethyl)-1-phenyl-4,5-dihydro-1H-pyrazole (1b): Yellowish white crystals (86\% yield); mp 176-177 ${ }^{\circ} \mathrm{C}$; IR $(\mathrm{KBr}) v\left(\mathrm{~cm}^{-1}\right): 1191.05$ (C-N of diazole), $1233.33\left(\mathrm{C}-\mathrm{O}-\mathrm{CH}_{3}\right), 1503.21$ (aromatic), 1619.02 (C=N of diazole); ${ }^{1} \mathrm{H}-\mathrm{NMR}$ (DMSO- $d_{6}, 500 \mathrm{MHz}$ ): $\delta 2.69\left(\mathrm{t}, 2 \mathrm{H}, \mathrm{CH}_{2} \mathrm{CH}_{2}\right), \delta 2.84\left(\mathrm{t}, 2 \mathrm{H}, \mathrm{CH}_{2} \mathrm{CH}_{2}\right), \delta 2.91(\mathrm{~d}, 2 \mathrm{H}$, diazole $\left.\mathrm{CH}_{2}\right), \delta 3.86\left(\mathrm{~s}, 3 \mathrm{H}, \mathrm{O}-\mathrm{CH}_{3}\right), \delta 5.24(\mathrm{t}, 1 \mathrm{H}$, diazole $\mathrm{CH}), \delta 6.92-7.77(\mathrm{~m}, 15 \mathrm{H}$, aromatic $\mathrm{H})$.

4-(3-(2-(6-Methoxynaphthalen-2-yl)ethyl)-1-phenyl-4,5dihydro-1H-pyrazol-5-yl)-N,N-dimethylaniline (1c): Yellowish white crystals (68\% yield); mp $181-183^{\circ} \mathrm{C}$; IR $(\mathrm{KBr}) v\left(\mathrm{~cm}^{-1}\right)$ : 1157.96 (C-N of diazole), $1261.27\left(\mathrm{C}-\mathrm{O}-\mathrm{CH}_{3}\right), 1515.07$ (aromatic), 1609.37 ( $\mathrm{C}=\mathrm{N}$ of diazole); ${ }^{1} \mathrm{H}-\mathrm{NMR}$ (DMSO- $d_{6}$, $500 \mathrm{MHz}): \delta 2.70\left(\mathrm{t}, 2 \mathrm{H}, \mathrm{CH}_{2} \mathrm{CH}_{2}\right), \delta 2.87\left(\mathrm{t}, 2 \mathrm{H}, \mathrm{CH}_{2} \mathrm{CH}_{2}\right), \delta$ $\left.2.95\left(\mathrm{~s}, 6 \mathrm{H}, \mathrm{N}\left(\mathrm{CH}_{3}\right)\right)_{2}\right), \delta 2.96\left(\mathrm{~d}, 2 \mathrm{H}\right.$, diazole $\left.\mathrm{CH}_{2}\right), \delta 3.86(\mathrm{~s}$, $\left.3 \mathrm{H}, \mathrm{O}-\mathrm{C}_{3}\right), \delta 5.27$ (t, $1 \mathrm{H}$, diazole $\left.\mathrm{C} \underline{\mathrm{H}}\right), \delta 6.68-7.70(\mathrm{~m}, 15 \mathrm{H}$, aromatic $\mathrm{H})$. 
3-(2-(6-Methoxynaphthalen-2-yl)ethyl)-5-phenyl-4,5-dihydroisoxazole (2a): White crystals (59\% yield); mp 145$147^{\circ} \mathrm{C}$; IR $(\mathrm{KBr}) v\left(\mathrm{~cm}^{-1}\right): 1071.73$ (C-O of isoxazoline), $1269.55\left(\mathrm{C}-\mathrm{O}-\mathrm{CH}_{3}\right), 1509.54$ (aromatic), $1601.04(\mathrm{C}=\mathrm{N}$ of diazole); ${ }^{1} \mathrm{H}-\mathrm{NMR}$ (DMSO- $\left.d_{6}, 500 \mathrm{MHz}\right): \delta 2.68\left(\mathrm{t}, 2 \mathrm{H}, \mathrm{CH}_{2}-\right.$ $\left.\mathrm{CH}_{2}\right), \delta 2.88\left(\mathrm{~d}, 2 \mathrm{H}\right.$, isoxazoline $\left.\mathrm{CH}_{2}\right), \delta 2.92\left(\mathrm{t}, 2 \mathrm{H}, \mathrm{CH}_{2}-\right.$ $\left.\mathrm{CH}_{2}\right), \delta 3.88\left(\mathrm{~s}, 3 \mathrm{H}, \mathrm{O}-\mathrm{C}_{3}\right), \delta 5.76(\mathrm{t}, 1 \mathrm{H}$, isoxazoline $\mathrm{C} \underline{\mathrm{H}})$, $\delta 7.10-7.80(\mathrm{~m}, 11 \mathrm{H}$, aromatic $\mathrm{H})$.

5-(4-Chlorophenyl)-3-(2-(6-methoxynaphthalen-2-yl) ethyl)-4,5-dihydroisoxazole (2b): White crystals (64\% yield); $\mathrm{mp} 166-169^{\circ} \mathrm{C}$; IR $(\mathrm{KBr}) v\left(\mathrm{~cm}^{-1}\right): 1081.79(\mathrm{C}-\mathrm{O}$ of isoxazoline), 1226.84 (C-O-CH3), 1599.41 (aromatic), $1612.08(\mathrm{C}=\mathrm{N}$ of diazole); ${ }^{1} \mathrm{H}-\mathrm{NMR}$ (DMSO- $d_{6}, 500 \mathrm{MHz}$ ): $\delta 2.67$ (t, $2 \mathrm{H}$, $\left.\mathrm{CH}_{2}-\mathrm{CH}_{2}\right), \delta 2.91\left(\mathrm{~d}, 2 \mathrm{H}\right.$, isoxazoline $\left.\mathrm{CH}_{2}\right), \delta 2.94(\mathrm{t}, 2 \mathrm{H}$, $\left.\mathrm{CH}_{2}-\mathrm{CH}_{2}\right), \delta 3.88\left(\mathrm{~s}, 3 \mathrm{H}, \mathrm{O}-\mathrm{CH}_{3}\right), \delta 5.79(\mathrm{t}, 1 \mathrm{H}$, isoxazoline $\mathrm{CH}), \delta 7.12-7.83(\mathrm{~m}, 10 \mathrm{H}$, aromatic $\mathrm{H})$.

4-(3-(2-(6-Methoxynaphthalen-2-yl)ethyl)-4,5-dihydroisoxazol-5-yl)-N,N-dimethylaniline (2c): White crystals (51\% yield); mp $159-160^{\circ} \mathrm{C}$; IR ( $\left.\mathrm{KBr}\right) v\left(\mathrm{~cm}^{-1}\right): 1055.97$ (C-O of isoxazoline), $1269.21 \quad\left(\mathrm{C}-\mathrm{O}-\mathrm{CH}_{3}\right), 1588.05$ (aromatic), 1613.99 (C=N of diazole); ${ }^{1} \mathrm{H}-\mathrm{NMR}$ (DMSO- $\left.d, 500 \mathrm{MHz}\right): \delta$ $2.68\left(\mathrm{t}, 2 \mathrm{H}, \mathrm{CH}_{2}-\mathrm{CH}_{2}\right), \delta 2.82\left(\mathrm{~d}, 2 \mathrm{H}\right.$, isoxazoline $\left.\mathrm{CH}_{2}\right), \delta 2.90$ $\left(\mathrm{t}, 2 \mathrm{H}, \mathrm{CH}_{2}-\mathrm{CH}_{2}\right), \delta 2.94\left(\mathrm{~s}, 6 \mathrm{H}, \mathrm{N}\left(\mathrm{CH}_{3}\right)_{2}\right), \delta 3.87(\mathrm{~s}, 3 \mathrm{H}, \mathrm{O}-$ $\left.\mathrm{CH}_{3}\right), \delta 5.80(\mathrm{t}, 1 \mathrm{H}$, isoxazoline $\mathrm{CH}), \delta 6.77-7.78(\mathrm{~m}, 10 \mathrm{H}$, aromatic $\mathrm{H})$.

4-(2-(6-Methoxynaphthalen-2-yl)ethyl)-6-phenylpyrimidin-2-amine (3a): Light yellow crystals (84\% yield); mp 182$183^{\circ} \mathrm{C}$; IR $(\mathrm{KBr}) v\left(\mathrm{~cm}^{-1}\right): 1143.43(\mathrm{C}-\mathrm{N}), 1277.47\left(\mathrm{C}-\mathrm{O}-\mathrm{CH}_{3}\right)$, 1499.31 (aromatic), 1613.47 ( $\mathrm{C}=\mathrm{N}$ of pyrimidine), 3395.13 and $3420.02\left(\mathrm{NH}_{2}\right) ;{ }^{1} \mathrm{H}-\mathrm{NMR}$ (DMSO- $\left.d_{6}, 500 \mathrm{MHz}\right): \delta 2.90(\mathrm{t}, 2 \mathrm{H}$,
$\left.\mathrm{CH}_{2}-\mathrm{CH}_{2}\right), \delta 3.06\left(\mathrm{t}, 2 \mathrm{H}, \mathrm{CH}_{2}-\mathrm{CH}_{2}\right), \delta 3.88\left(\mathrm{~s}, 3 \mathrm{H}, \mathrm{O}-\mathrm{CH}_{3}\right)$, $\delta 7.10-8.10(\mathrm{~m}, 12 \mathrm{H}$, aromatic $\mathrm{H}), \delta 8.15\left(\mathrm{~d}, 2 \mathrm{H}, \mathrm{NH}_{2}\right)$.

4-(4-Chlorophenyl)-6-(2-(6-methoxynaphthalen-2-yl) ethyl)pyrimidin-2-amine (3b): Light yellow crystals $(78 \%$ yield); $\mathrm{mp} 204-206^{\circ} \mathrm{C}$; IR (KBr) $v\left(\mathrm{~cm}^{-1}\right): 1273.73\left(\mathrm{C}-\mathrm{O}-\mathrm{CH}_{3}\right)$, 1503.52 (aromatic), 1613.75 ( $\mathrm{C}=\mathrm{N}$ of pyrimidine), 3369.52 and $3391.13\left(\mathrm{NH}_{2}\right) ;{ }^{1} \mathrm{H}-\mathrm{NMR}$ (DMSO- $\left.d_{6}, 500 \mathrm{MHz}\right): \delta 2.98(\mathrm{t}$, $\left.2 \mathrm{H}, \mathrm{CH}_{2}-\mathrm{CH}_{2}\right), \delta 3.07$ (t, $\left.2 \mathrm{H}, \mathrm{CH}_{2}-\mathrm{CH}_{2}\right), \delta 3.95$ (s, 3H, O$\left.\mathrm{CH}_{3}\right), \delta 7.12-8.09(\mathrm{~m}, 11 \mathrm{H}$, aromatic $\mathrm{H}), \delta 7.81\left(\mathrm{~d}, 2 \mathrm{H}, \mathrm{NH}_{2}\right)$.

4-(4-(Dimethylamino)phenyl)-6-(2-(6-methoxynaphthalen-2-yl)ethyl)pyrimidin-2-amine (3c): Light yellow crystals (67\% yield); mp $195-196^{\circ} \mathrm{C}$; $\mathrm{IR}(\mathrm{KBr}) v\left(\mathrm{~cm}^{-1}\right): 1189.64(\mathrm{C}-\mathrm{N})$, $1304.49\left(\mathrm{C}-\mathrm{O}-\mathrm{CH}_{3}\right), 1481.62$ (aromatic), $1611.58(\mathrm{C}=\mathrm{N}$ of pyrimidine), 3394.21 and $3476.65\left(\mathrm{NH}_{2}\right)$; ${ }^{1} \mathrm{H}-\mathrm{NMR}$ (DMSO$\left.d_{6}, 500 \mathrm{MHz}\right): \delta 2.80\left(\mathrm{t}, 2 \mathrm{H}, \mathrm{CH}_{2}-\mathrm{CH}_{2}\right), \delta 2.90\left(\mathrm{t}, 2 \mathrm{H}, \mathrm{CH}_{2}-\right.$ $\left.\mathrm{CH}_{2}\right), \delta 2.99\left(\mathrm{~s}, 6 \mathrm{H}, \mathrm{N}\left(\mathrm{CH}_{3}\right)_{2}\right), \delta 3.87\left(\mathrm{~s}, 3 \mathrm{H}, \mathrm{O}-\mathrm{CH}_{3}\right), \delta$ 6.73-7.75 (m, $11 \mathrm{H}$, aromatic $\mathrm{H}), \delta 7.68\left(\mathrm{~d}, 2 \mathrm{H}, \mathrm{NH}_{2}\right)$.

\section{Computational Method}

The computational approach adopted in this work is outlined in Fig. 2. A full licensed CCDC genetic optimization for ligand docking (GOLD) Suite (v. 5.6.2) was used to perform the molecular docking studies for the compounds. CCDC Hermes visualizer software (v. 1.9.2) was used to visualize: the protein, ligands, hydrogen bonding interactions, short contacts and bonds length calculation. The chemical structures of our ligands were drawn using ChemBioOffice software (v. 17.1).

The pharmacokinetic profile, i.e., adsorption, distribution, metabolism, excretion (ADME) of the synthesized compounds was predicted with the help of Swiss ADME server. ${ }^{40}$

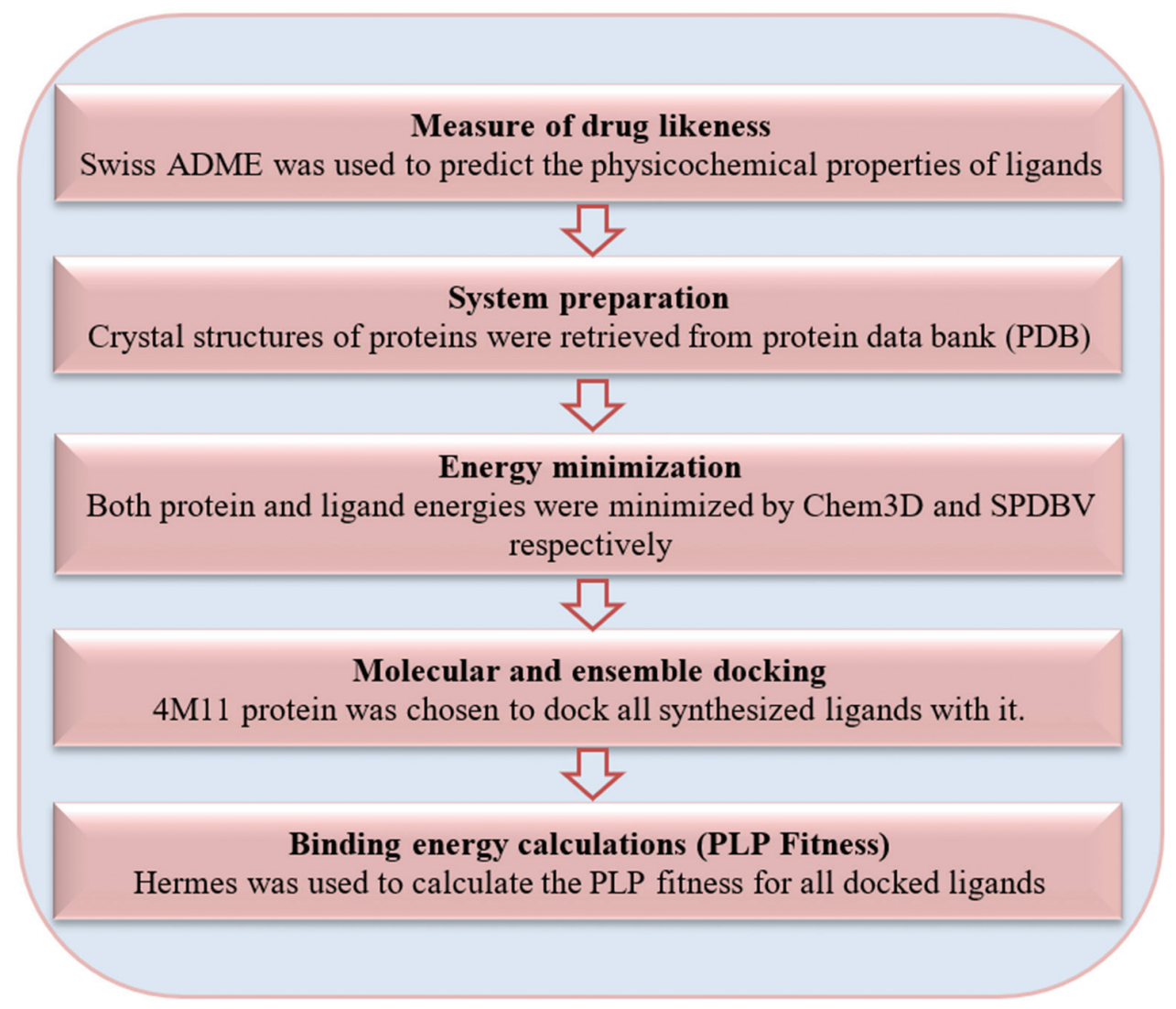

Fig. 2 Outline of computational protocol. 


\section{ADME procedures}

All ligands (1-3c) were drawn by ChemSketch (v. 12), converted to SMILE name by Swiss ADME tool which predicts the physicochemical descriptors and pharmacokinetic properties. BOILED-EGG was used to compute the lipophilicity and polarity of the small molecule. ${ }^{14}$

\section{Preparation of ligands and protein receptor}

The crystal structures of the enzyme COX 1 [PDB ID: 3N8Z] and COX 2 [PDB ID: 4M11] were downloaded from the Protein Data Bank (PDB), and their missing atoms were added with the assistance of Swiss PDB Viewer (v. 3.7). The crystal structures of our downloaded proteins were prepared by removing all water molecules and by adding hydrogen atoms to get a correct ionization and tautomeric states of amino acid residues. CheBio3D (v. 17.1) was used to minimize the energy for our synthesized ligands by applying the MM2 force field.

\section{Docking procedures}

The full license version of GOLD (v. 5.6.2) was used for the molecular docking. ${ }^{42,43}$ The Hermes visualizer software in the GOLD Suite was used to set up the receptors for the docking process additionally. The binding site used for GOLD docking was defined as all the protein residues within the $10 \AA$ of the reference ligands that exist in the downloaded protein structure complexes. Five COX-2 proteins were downloaded from the PDB website (1pxx, 4m11, 3LN1, 3KK6 and 5kIR) to perform the process of ensemble docking. ${ }^{44}$ As a result, $4 \mathrm{~m} 11$ was chosen for the process of docking study for the compounds. The cavity and the active site were determined by using CCDC Superstar. The reference ligand of the protein was used to determine the radius (10 $\AA$ ) of the active site. ChemScore kinase has been used as a configuration template. ChemPiecewise linear potential (CHEMPLP) was used for the scoring function. The values of all parameters used during the process of docking were kept the default, and all solutions are scored according to CHEMPLP fitness function. According to CHEMPLP, the steric complementary between protein and ligand is calculated while the distance and angle-dependent hydrogen are considered. The results of docking, i.e., the binding mode, docked pose, and binding free energy were studied to evaluate the interaction between the amino acids residues of the proteins COX-1 and COX-2 and our synthesized ligands.

\section{Results and Discussion}

Many irritant agents have been used in the paw-edema method such as dextran, egg-white, and carrageenan solution. The intraplantar injection of egg-white into rat hind paw induces a progressive edema. To assess the validity of the method (pawedema) used for the evaluation of newly synthesized antiinflammatory compounds, nabumetone was used as a reference compound of known anti-inflammatory activity profile, the results are shown in Table 1 and Fig. 3.

Non-identical superscripts ( $a, b$ and $c$ ) among different examined agents were considered significantly different $(p<0.05)$

Numbers are stated in mm paw width as mean \pm SEM. $n=$ number of rats. Time (0) is the time of i.p. injection of tested compounds. Time (30) is the time of egg-white injection.

\section{Molecular Modeling}

Genetic optimization for ligand docking is a "genetic algorithm for docking flexible ligands into protein binding sites". ${ }^{45}$ GOLD has been broadly verified and has shown superb rendering for pose prediction and excellent results for virtual screening. ${ }^{46}$ It is provided as a part of the GOLD Suite, which contains additional software components, Hermes, Mercury, Isostar and Conquest, and GoldMine, etc.

Energy minimization for ligands and proteins can fix distorted geometries by moving atoms to release internal constraints. After minimization of the energy, the geometry is repaired which means a minimum of energy has been reached.

To predict the selectivity and binding energies of the synthesized compounds for COX-1 and COX-2, docking studies were performed with the help of GOLD Suite software to study the molecular interactions involved in between active binding sites of protein target and the synthesized compounds $(\mathbf{1}-\mathbf{3 c})$.

The COXs inhibitory activity of the compounds $1-3 c$, 6MNA, diclofenac, and naproxen were ranked based on their PLP fitness involved in the complex formation at the active sites. The PLP fitness of the docked compounds on COX-1 and COX-2 was found in the range of 42.9-72.2 and 75.7-93.3, respectively (Table 2).

There is an excellent agreement between our docked results and experimental results (In vivo study).

\begin{tabular}{|c|c|c|c|c|c|c|c|c|}
\hline & \multirow{2}{*}{ Compounds } & \multicolumn{7}{|c|}{ Time (min) } \\
\hline & & 0 & 30 & 60 & 120 & 180 & 240 & 300 \\
\hline \multirow{7}{*}{ 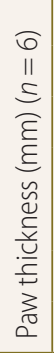 } & Control & $4.56 \pm 0.05$ & $5.60 \pm 0.02$ & $6.65 \pm 0.04$ & $7.48 \pm 0.03$ & $7.61 \pm 0.03$ & $6.98 \pm 0.05$ & $5.78 \pm 0.02$ \\
\hline & Nabumetone & $4.58 \pm 0.04$ & $5.57 \pm 0.03$ & $6.58 \pm 0.03$ & $7.36 \pm 0.02$ & $7.45 \pm 0.06$ & $6.77 \pm 0.05$ & $5.12 \pm 0.02^{b^{*}}$ \\
\hline & $1 c$ & $4.55 \pm 0.02$ & $5.51 \pm 0.04$ & $5.85 \pm 0.05^{\mathrm{a}^{*}}$ & $5.32 \pm 0.02^{2^{*}}$ & $4.94 \pm 0.03^{\mathrm{a}^{*}}$ & $4.74 \pm 0.01^{\mathrm{a}^{*}}$ & $4.65 \pm 0.03^{\mathrm{a}^{*}}$ \\
\hline & $2 a$ & $4.61 \pm 0.02$ & $5.63 \pm 0.05$ & $6.67 \pm 0.03$ & $6.94 \pm 0.04^{b^{*}}$ & $6.48 \pm 0.05^{b^{*}}$ & $5.98 \pm 0.06^{b^{*}}$ & $4.98 \pm 0.05^{b^{*}}$ \\
\hline & $2 b$ & $4.59 \pm 0.04$ & $5.64 \pm 0.06$ & $6.21 \pm 0.05^{b^{*}}$ & $5.91 \pm 0.04^{*}$ & $5.59 \pm 0.03^{c^{*}}$ & $5.25 \pm 0.07 \mathrm{c}^{*}$ & $4.94 \pm 0.04^{b^{*}}$ \\
\hline & $3 b$ & $4.54 \pm 0.03$ & $5.59 \pm 0.04$ & $6.29 \pm 0.02^{b^{*}}$ & $5.97 \pm 0.06^{*}$ & $5.65 \pm 0.04^{*}$ & $5.23 \pm 0.01^{c^{*}}$ & $4.89 \pm 0.03^{b^{*}}$ \\
\hline & $3 c$ & $4.57 \pm 0.02$ & $5.63 \pm 0.05$ & $5.90 \pm 0.03^{\mathrm{a}^{*}}$ & $5.43 \pm 0.03^{a^{*}}$ & $5.09 \pm 0.02^{2^{*^{*}}}$ & $4.84 \pm 0.05^{\mathrm{a}^{*}}$ & $4.71 \pm 0.04^{a^{*}}$ \\
\hline
\end{tabular}

*Significantly different compared with control agent $(p<0.05)$. 


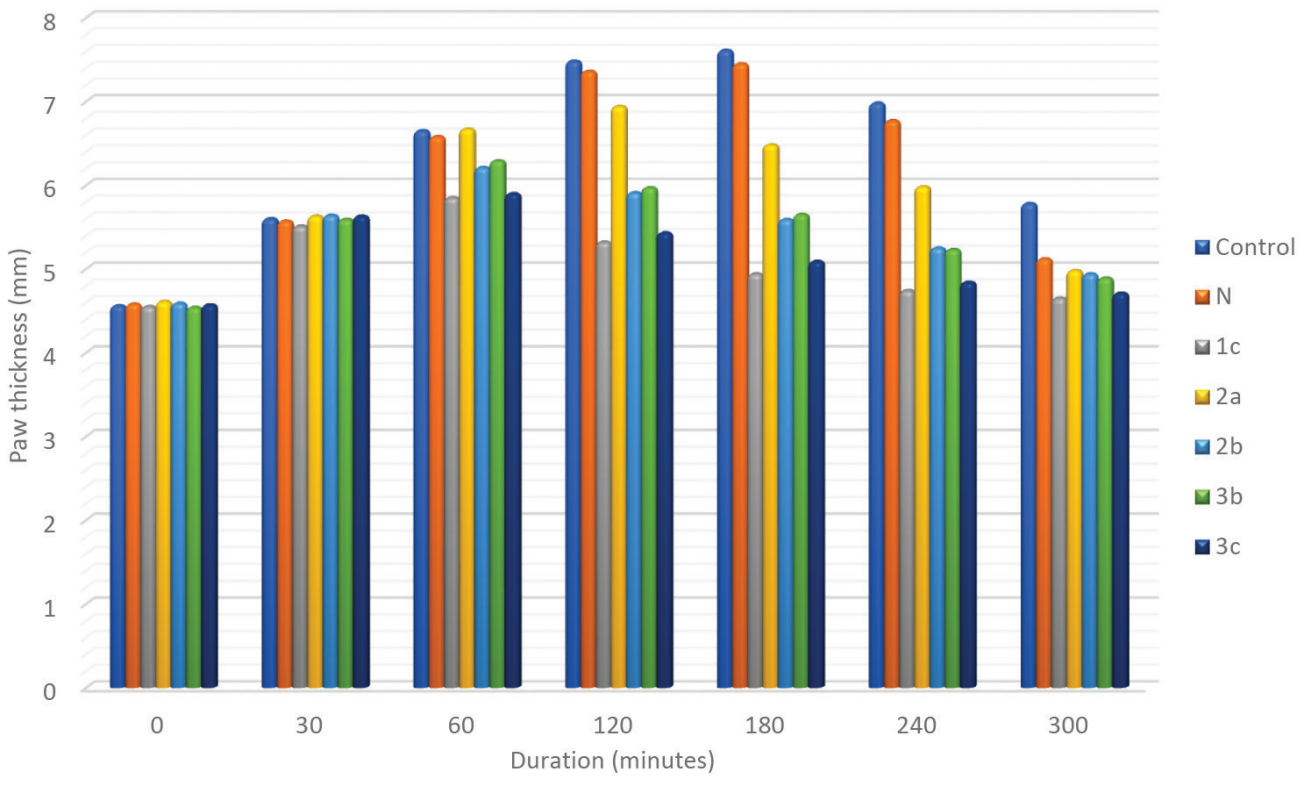

Fig. 3 Effect of propylene glycol, nabumetone, compounds (1c, 2a, 2b, 3b, and 3c) on egg-white provoked paw edema in rats.

\begin{tabular}{|c|c|c|c|c|}
\hline Compounds & $\begin{array}{l}\text { COX-2 binding energy } \\
\text { (PLP Fitness) (Kcal/mol) }\end{array}$ & $\begin{array}{c}\text { Amino acids included in } \\
\mathrm{H} \text {-bonding }\end{array}$ & $\begin{array}{l}\text { Amino acids included in hydrophobic } \\
\text { interactions }\end{array}$ & $\begin{array}{l}\text { COX-1 binding energy } \\
\text { (PLP Fitness) (Kcal/mol) }\end{array}$ \\
\hline 6MNA & 60.22 & Tyr355 and Arg120 & Gly526, Val523, Trp387, Arg120, and Tyr355 & 67.36 \\
\hline 1 & 81.89 & Tyr355 & Ala527, Tyr355, and Leu531 & 63.33 \\
\hline 2 & 75.71 & Ser530 & Leu531, Val116, Leu534, and Ser530 & 67.21 \\
\hline 3 & 86.11 & $\operatorname{Arg} 120$ & Arg120, Tyr355, and Val523 & 66.87 \\
\hline $1 \mathrm{a}$ & 87.56 & - & Leu345, Val116, and Arg120 & 46.75 \\
\hline $1 b$ & 80.94 & Tyr355 & Leu354, Leu359, Leu345, Tyr355, Val523, and Val349 & 46.64 \\
\hline $1 \mathrm{c}$ & 93.33 & - & $\begin{array}{l}\text { Leu531, Leu345, Leu359, Val116, Tyr355, Val523, } \\
\text { and Val89. }\end{array}$ & 42.99 \\
\hline $2 \mathrm{a}$ & 73.16 & Tyr355 and Arg120 & Val523, Trp387, Ala527, and Tyr355 & 72.29 \\
\hline $2 b$ & 80.30 & Tyr355 and Arg120 & $\begin{array}{l}\text { Tyr355, Arg120, Val523, Val349, Leu531, Leu345, } \\
\text { and Met535 }\end{array}$ & 66.35 \\
\hline $2 c$ & 83.51 & $\operatorname{Arg} 120$ & Leu531, Ile345, Leu359, Val116, and Arg120 & 61.97 \\
\hline 3a & 86.96 & Val116 & Leu354, Tyr355, Val523, and Gly526 & 71.19 \\
\hline $3 b$ & 85.39 & Ser530 & Leu359, Tyr355, Arg120, and Val523 & 57.72 \\
\hline $3 c$ & 87.50 & Arg120 and Tyr355 & $\begin{array}{l}\text { Leu531, Leu534, Leu345, Val116, Arg120, and } \\
\text { Tyr355 }\end{array}$ & 61.50 \\
\hline Diclofenac & 71.7 & Ser530 and Tyr385 & Ala527, Val349, Gly526, and Trp387 & 68.60 \\
\hline Naproxen & 74.23 & Arg120 and Tyr355 & $\begin{array}{l}\text { Ser530, Ala527, Gly526, Val349, Leu352, and } \\
\text { Val523 }\end{array}$ & 63.12 \\
\hline
\end{tabular}

${ }^{*}$ COX-1 PDB code $=[1 \mathrm{cqe}]$.

${ }^{*}$ COX-2 PDB code $=[4 \mathrm{~m} 11]$

Ensemble docking is very important that is because reduces the risk of inadvertently choosing an unsuitable protein model, improvement in pose prediction, virtual screening enrichments, and to make sure that the process of docking is in the right way, that is why we made ensemble docking in the first step by using five different COX-2 proteins.

Docking analysis indicted that Arg120, Tyr355, Ser530, Val116, Tyr385, Gly526, Val523, Trp387, Ala527, Leu531, Leu534, Leu345, Leu539, Val89, Val349, shown in Fig. 1 and listed in Table 2 of this enzyme, interact through hydrogen bonding and short contacts with our final ligands library.
The distance of short contacts and hydrogen bonding between a specific protein atom and our synthesized ligands is calculated by GOLD and all bonds length below $3 \AA^{47}$ The short contacts are defined as other interactive forces such as van der Waals, electrostatic, steric, p-p stacking, dipoledipole, and others.

All the synthesized compounds having promising docking results with COXs, fitted in the COX-2 active site as shown in Figs. 3-9, COX-1 results showed a lower binding energy because COX-2 active site is bigger than COX-1 active site, and the synthesized compounds have large structure that makes difficulty in the insertion in COX-1 enzyme pocket. 


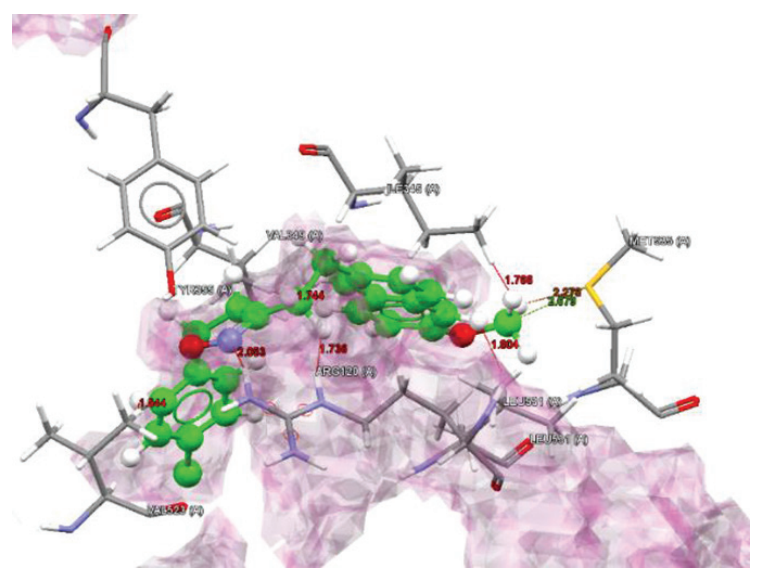

Fig. 4 Short contacts interaction profile for the compound $2 b$. The interaction between compound $2 \mathrm{~b}$ and amino acid residues Tyr355, Arg120, Val523, Val349, Leu531, Leu345, and Met535 [2b: Ball and stick style, amino acid residues in capped stick style and the active site pocket in purple color].

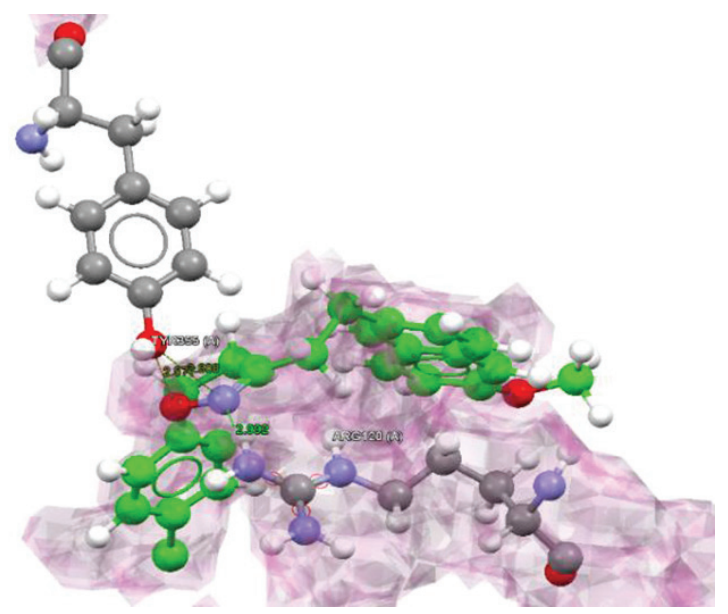

Fig. 5 Hydrogen bond interaction profile for the compound $2 \mathrm{~b}$. The interaction between compound $2 \mathrm{~b}$ and amino acid residues Tyr355 and Arg120 [2b: Ball and stick style, amino acid residues in a gray ball and stick style and the active site pocket in purple color].

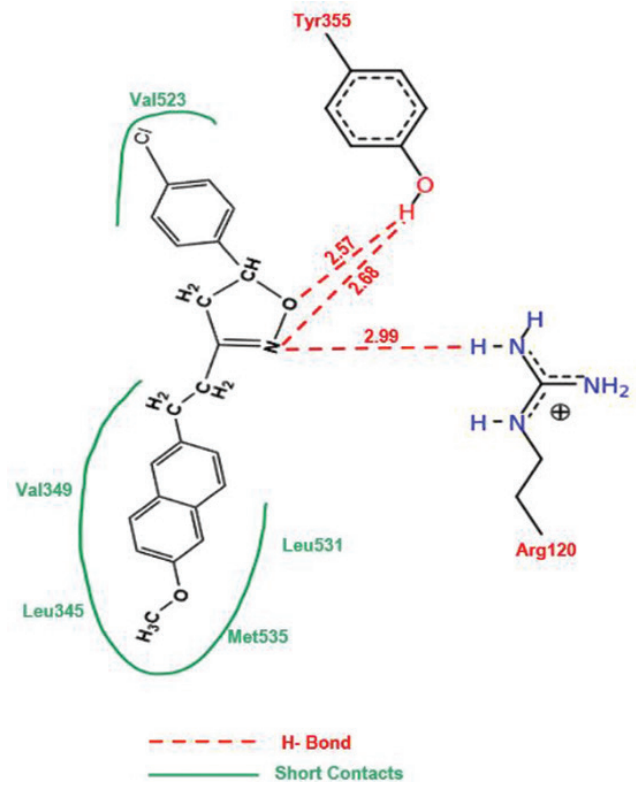

Fig. 6 2D diagram and interactions of compound $2 \mathbf{b}$.

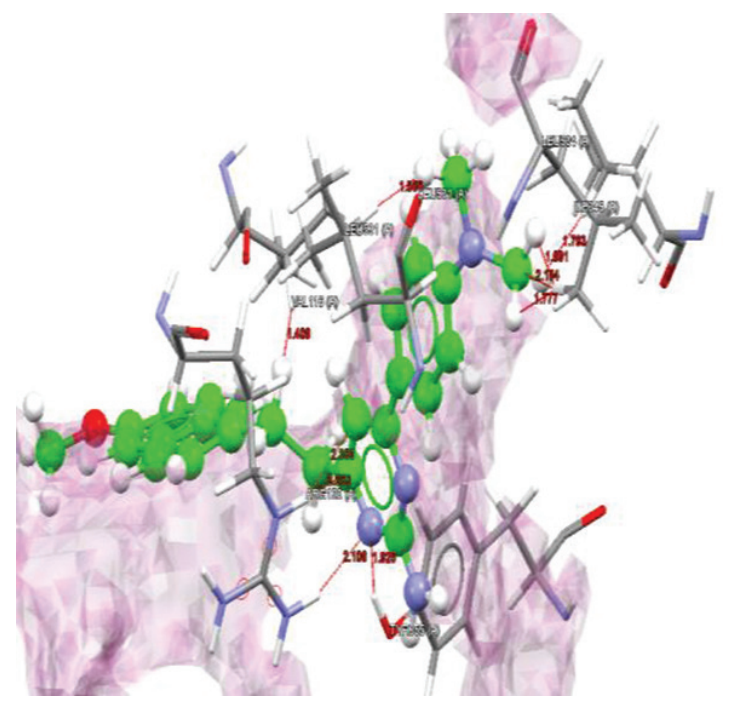

Fig. 7 Short contacts interaction profile for the compound 3c. The interaction between compound $3 \mathrm{c}$ and amino acid residues Leu531, Leu534, Leu345, Val116, Arg120, and Tyr355 [3c: Ball and stick style, amino acid residues in capped stick style and the active site pocket in purple color].

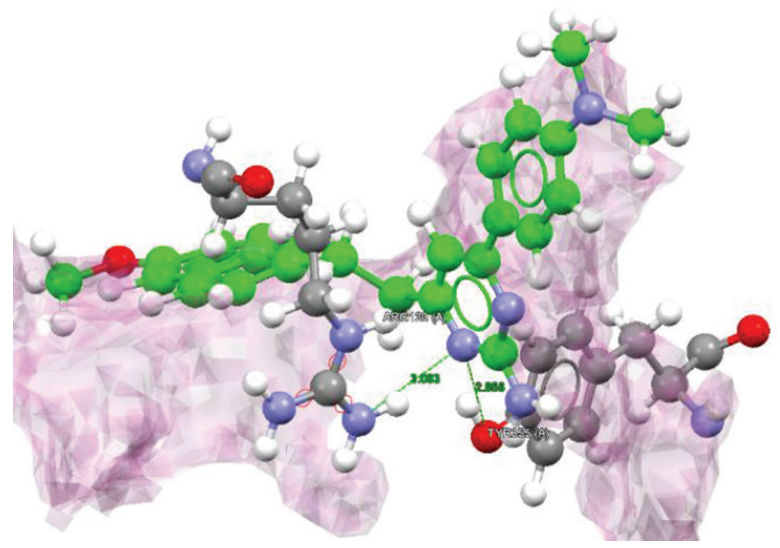

Fig. 8 Hydrogen bond interaction profile for the compound 3c. The interaction between compound $3 \mathrm{c}$ and amino acid Arg120 and Tyr355 [3c: Ball and stick style, amino acid residues in capped stick style and the active site pocket in purple color].

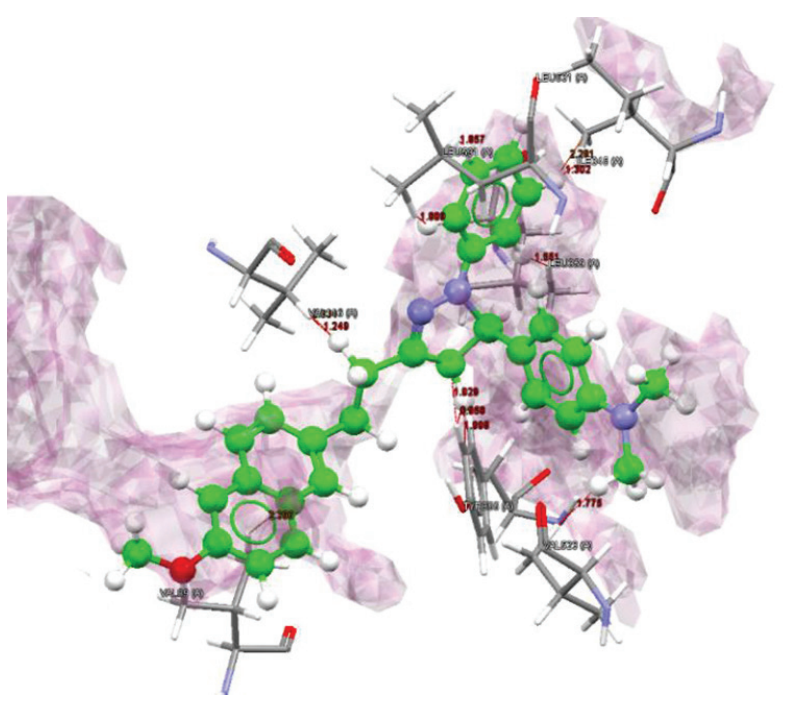

Fig. 9 2D diagram and interactions of compound 3C. 
Compound 2b (Figs. 4-6) and 3c (Figs. 7-9) show H-bond interactions with Arg120 and Tyr355 and these two amino acids exist in the binding with five approved NSAIDs (Ibuprofen, Naproxen, Indomethacin, Flurbiprofen and Des-methylflurbiprofen). Compound $\mathbf{2}$ and $\mathbf{3 b}$ have H-bond with Ser530 which is the binding site of diclofenac, lumiracoxib, tolfenamic acid. Compound $\mathbf{1}$ and $\mathbf{1 b}$ each have one $\mathrm{H}$-bond with Tyr355 like in aspirin.

Compound 1c shows the best docking PLP fitness which was 93.33 with COX-2 and 42.99 with COX-1, there was no H-bond contacts, only short contacts (13 contacts) with Leu531, Leu345, Leu359, Val116, Tyr355, Val523 and Val89 as in Fig. 10. Little hydrophobic contacts give lower biological activity when the number of hydrophobic contacts increases the biological activity will increase because these

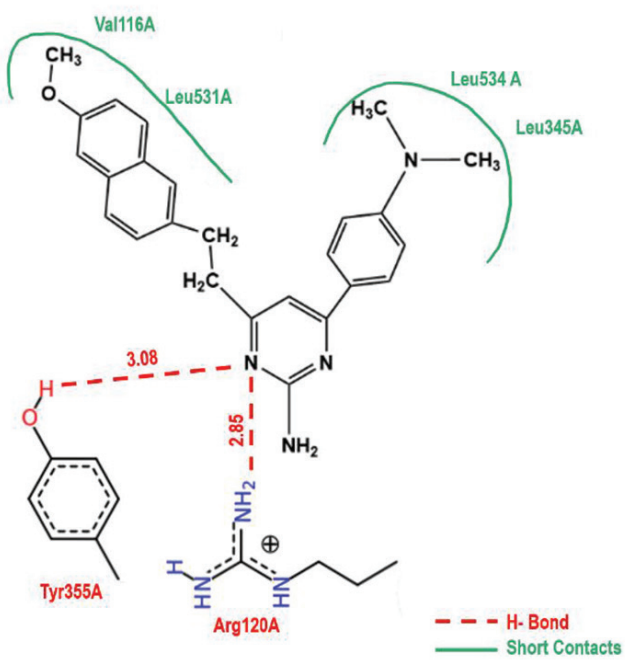

Fig. 10 Short contacts interaction profile for the compound $1 \mathrm{c}$. The interaction between compound $1 \mathrm{c}$ and amino acid residues Leu531, Leu345, Leu359, Val116, Tyr355, Val523, and Val89 [1c: Ball and stick style, amino acid residues in capped stick style and the active site pocket in purple color]. contacts will outweigh the $\mathrm{H}$-bonding contacts and these bonds play a crucial role in the binding of a substrate to an active site. ${ }^{48}$

\section{ADME Studies}

The ADME properties profile of our synthesized compounds were studied by Swiss ADME server to detect the safer and potential drug candidate(s) to filter out the compounds which are most likely to fail in the subsequent stages of drug development due to unfavorable ADME properties.

We assessed all synthesized compounds ADME method.

Also, we calculated the topological polar surface area (TPSA), since it is another critical property that has been linked to the drug bioavailability. Thus, passively absorbed molecules with a TPSA > $140 \AA$ are thought to have low oral bioavailability. ${ }^{49}$ Our results showed that all synthesized compounds have TPSA below 140, which is in the range of 24-64 and the bioavailability for all ligands was 0.55 which mean that all ligands reach the systemic circulation.

Compound 3, 2a, 2c, 3a, 3b, and 3c fulfilled Lipinski rule. Also, it also fulfilled the topological descriptors and fingerprints of molecular drug-likeness structure keys as $\log P$ and LogS.

The GI absorption score is a measure of the extent of absorption of a molecule from the intestine following oral administration. The absorption could be excellent if the result were high. In this study, the GI absorption of all compounds was high predicting them to be well absorbed from the intestine.

The ADME properties profile for the synthesized compounds are illustrated in Table 3.

\section{Conclusion}

1. The synthesis of the designed compounds has been successfully achieved.

2. Characterization and identification of the synthesized compounds were confirmed by determination of physical properties (melting point, description and TLC), FT-IR spectroscopy and ${ }^{1} \mathrm{H}-\mathrm{NMR}$ spectra.

\begin{tabular}{|c|c|c|c|c|c|c|c|c|c|}
\hline Compounds & Formula & $\begin{array}{c}\text { M.Wt } \\
(\mathrm{g} / \mathrm{mol})\end{array}$ & $\begin{array}{l}\text { H-bond } \\
\text { acceptors }\end{array}$ & $\begin{array}{l}\text { H-bond } \\
\text { donors }\end{array}$ & MR & TPSA & GI Abs. & $\begin{array}{c}\text { BBB } \\
\text { permeant }\end{array}$ & $\begin{array}{c}\text { Lipiniski } \\
\text { violations }\end{array}$ \\
\hline $\mathrm{N}$ & $\mathrm{C}_{15} \mathrm{H}_{16} \mathrm{O}_{2}$ & 228.29 & 2 & 0 & 70.03 & $26.30 \AA^{2}$ & High & Yes & 0 \\
\hline 1 & $\mathrm{C}_{22} \mathrm{H}_{20} \mathrm{O}_{2}$ & 316.39 & 2 & 0 & 99.64 & $26.30 \AA^{2}$ & High & Yes & 1 \\
\hline 2 & $\mathrm{C}_{22} \mathrm{H}_{19} \mathrm{ClO}_{2}$ & 350.84 & 2 & 0 & 104.65 & $26.30 \AA^{2}$ & High & Yes & 1 \\
\hline 3 & $\mathrm{CH}_{25} \mathrm{NO}_{2}$ & 359.46 & 2 & 0 & 113.85 & $29.54 \AA^{2}$ & High & Yes & 0 \\
\hline $1 \mathrm{a}$ & $\mathrm{C}_{28} \mathrm{H}_{26} \mathrm{~N}_{2} \mathrm{O}$ & 406.52 & 2 & 0 & 135.87 & $24.83 \AA^{2}$ & High & Yes & 1 \\
\hline $1 b$ & $\mathrm{C}_{28} \mathrm{H}_{25} \mathrm{ClN}_{2} \mathrm{O}$ & 440.96 & 2 & 0 & 140.88 & $24.83 \AA^{2}$ & High & No & 1 \\
\hline $1 c$ & $\mathrm{C}_{30} \mathrm{H}_{31} \mathrm{~N}_{3} \mathrm{O}$ & 449.59 & 2 & 0 & 150.08 & $28.07 \AA^{2}$ & High & Yes & 1 \\
\hline $2 a$ & $\mathrm{C}_{22} \mathrm{H}_{21} \mathrm{NO}_{2}$ & 331.41 & 3 & 0 & 105.10 & $30.82 \AA^{2}$ & High & Yes & 0 \\
\hline $2 b$ & $\mathrm{C}_{22} \mathrm{H}_{20} \mathrm{ClNO}_{2}$ & 365.85 & 3 & 0 & 110.11 & $30.82 \AA^{2}$ & High & Yes & 1 \\
\hline $2 c$ & $\mathrm{C}_{24} \mathrm{H}_{26} \mathrm{~N}_{2} \mathrm{O}_{2}$ & 374.48 & 3 & 0 & 119.31 & $34.06 \AA^{2}$ & High & Yes & 0 \\
\hline 3a & $\mathrm{C}_{23} \mathrm{H}_{21} \mathrm{~N}_{3} \mathrm{O}$ & 355.43 & 3 & 1 & 110.13 & $61.03 \AA^{2}$ & High & Yes & 0 \\
\hline $3 b$ & $\mathrm{C}_{23} \mathrm{H}_{20} \mathrm{ClN}_{3} \mathrm{O}$ & 389.88 & 3 & 1 & 115.14 & $61.03 \AA^{2}$ & High & Yes & 0 \\
\hline $3 c$ & $\mathrm{C}_{25} \mathrm{H}_{26} \mathrm{~N}_{4} \mathrm{O}$ & 398.50 & 3 & 1 & 124.34 & $64.27 \AA^{2}$ & High & Yes & 0 \\
\hline
\end{tabular}


3. The anti-inflammatory assessment of the final products indicates that the incorporation of pyrazoline, isoxazoline, and pyrimidine pharmacophore into nabumetone improved its anti-inflammatory action.

4. The ADME studies showed compound 3, 2a, 2c, 3a, 3b, and $3 c$ fulfilled the Lipinski rule, and all synthesized compounds absorbed from GIT.

5. Docking studies showed a perfect agreement with in vivo study.
6. The preliminary study of anti-inflammatory activity showed that compounds $\mathbf{1 c}$ and $\mathbf{3 c}$ have significantly more anti-inflammatory outcome than all compounds.

\section{Conflict of Interest}

None.

\section{References}

1. da Costa BR, Reichenbach S, Keller N, Nartey L, Wandel S, Jüni P, et al. Effectiveness of non-steroidal anti-inflammatory drugs for the treatment of pain in knee and hip osteoarthritis: a network meta-analysis. Lancet. 2017:390: e21-e33.

2. Marnett LJ, Kalgutkar AS. Design of selective inhibitors of cyclooxygenase-2 as nonulcerogenic anti-inflammatory agents. Curr Opin Chem Biol. 1998;2:482-490

3. Takahashi M, Ogawa T, Kashiwagi H, Fukushima F, Yoshitsugu M, Haba $M$, et al. Chemical synthesis of an indomethacin ester prodrug and its metabolic activation by human carboxylesterase 1. Bioorg Med Chem Lett 2018:28:997-1000

4. Mahdi MF, Mohammed MH, Jassim AA. Design, synthesis and preliminary pharmacological evaluation of new non-steroidal anti-inflammatory agents having a 4-(methylsulfonyl) aniline pharmacophore. Molecules. 2012:17:1751-1763.

5. Kalgutkar AS, Rowlinson SW, Crews BC, Marnett LJ. Amide derivatives of meclofenamic acid as selective cyclooxygenase-2 inhibitors. Bioorg Med Chem Lett. 2002;12:521-524.

6. Kalgutkar AS, Crews BC, Saleh S, Prudhomme D, Marnett LJ. Indolyl esters and amides related to indomethacin are selective COX-2 inhibitors. Bioorg Med Chem. 2005;13:6810-6822.

7. Khanna S, Madan M, Vangoori A, Banerjee R, Thaimattam R, Basha SJ, et al. Evaluation of glycolamide esters of indomethacin as potential cyclooxygenase-2 (COX-2) inhibitors. Bioorg Med Chem. 2006:14: 4820-4833.

8. Ermondi G, Caron G, Lawrence R, Longo D. Docking studies on NSAID/COX2 isozyme complexes using contact statistics analysis. J Comput Aided Mol Des. 2004;18:683-696.

9. Luong C, Miller A, Barnett J, Chow J, Ramesha C, Browner MF. Flexibility of the NSAID binding site in the structure of human cyclooxygenase-2. Nat Struct Biol. 1996:3:927-933.

10. Kurumbail RG, Stevens AM, Gierse JK, McDonald JJ, Stegeman RA, Pak JY, et al. Structural basis for selective inhibition of cyclooxygenase-2 by antiinflammatory agents. Nature. 1996;384:644-648.

11. Bayly Cl, Black WC, Léger S, Ouimet N, Ouellet M, Percival MD. Structurebased design of COX-2 selectivity into flurbiprofen. Bioorg Med Chem Lett. 1999:9:307-312.

12. Chakraborti AK, Garg SK, Kumar R, Motiwala HF, Jadhavar PS. Progress in COX-2 inhibitors: a journey so far. Curr Med Chem. 2010;17:1563-1593.

13. Llorens O, Perez JJ, Palomer A, Mauleon D. Structural basis of the dynamic mechanism of ligand binding to cyclooxygenase. Bioorg Med Chem Lett. 1999:9:2779-2784

14. Friedman HL. Influence of isosteric replacements upon biological activity. NASNRS. 1951;206:295-358.

15. Lolli ML, Cena C, Medana C, Lazzarato L, Morini G, Coruzzi G, et al. A new class of ibuprofen derivatives with reduced gastrotoxicity. J Med Chem. 2001:44:3463-3468.

16. Prabhakar C, Reddy GB, Reddy CM, Nageshwar D, Devi AS, Babu JM, et al. Process research and structural studies on nabumetone. Org. Proc. Res. Dev. 1999;3:121-125

17. Kachroo M, Panda R, Yadav Y. Synthesis and biological activities of some new pyrimidine derivatives from chalcones. Pharm Chem. 2014;6:352-359.

18. Aksöz BE, Ertan R. Chemical and structural properties of chalcones I. FABAD J Pharm Sci. 2011;36:223-242.

19. Israf DA, Khaizurin TA, Syahida A, Lajis NH, Khozirah S. Cardamonin inhibits COX and iNOS expression via inhibition of p65NF-kB nuclear translocation and IK-B phosphorylation in RAW 264.7 macrophage cells. Mol Immunol. 2007:44:673-679.

20. Kim DW, Curtis-Long MJ, Yuk HJ, Wang Y, Song YH, Jeong SH, et al. Quantitative analysis of phenolic metabolites from different parts of
Angelica keiskei by HPLC-ESI MS/MS and their xanthine oxidase inhibition. Food Chem. 2014;153:20-27.

21. Yamamoto T, Yoshimura M, Yamaguchi F, Kouchi T, Tsuji R, Saito M, et al. Anti-allergic activity of naringenin chalcone from a tomato skin extract. Biosci Biotechnol Biochem. 2004;68:1706-1711.

22. Aoki N, Muko M, Ohta E, Ohta S. C-geranylated chalcones from the stems of Angelica keiskei with superoxide-scavenging activity. J Nat Prod. 2008:71:1308-1310

23. Birari RB, Gupta S, Mohan CG, Bhutani KK. Antiobesity and lipid lowering effects of Glycyrrhiza chalcones: experimental and computational studies. Phytomedicine. 2011;18(8-9):795-801.

24. Chen M, Christensen SB, Blom J, Lemmich E, Nadelmann L, Fich K, et al. Licochalcone $\mathrm{A}$, a novel antiparasitic agent with potent activity against human pathogenic protozoan species of Leishmania. Antimicrob Agents Chemother. 1993;37:2550-2556.

25. Cho S, Kim S, Jin Z, Yang H, Han D, Baek NI, et al. Isoliquiritigenin, a chalcone compound, is a positive allosteric modulator of GABA A receptors and shows hypnotic effects. Biochem Biophys Res Commun. 2011;413:637-642.

26. Siddiqui N, Alam P, Ahsan W. Design, synthesis, and in-vivo pharmacological screening of N,3-(substituted diphenyl)-5-phenyl$1 \mathrm{H}$-pyrazoline-1-carbothioamide derivatives. Arch Pharm (Weinheim). 2009;342:173-181.

27. Mahdi MF, Raauf AM, Mohammed NM. Synthesis, characterization and preliminary pharmacological evaluation of new non-steroidal antiinflammatory pyrazoline derivatives. Eur J Chem. 2015;6:461-467.

28. Trivedi AR, Dodiya DK, Ravat NR, Shah VH. Synthesis and biological evaluation of some new pyrimidines via a novel chalcone series. ARKIVOC. 2008:11:131-141.

29. Khoje AD, Kulendrn A, Charnock C, Wan B, Franzblau S, Gundersen LL. Synthesis of non-purine analogs of 6-aryl-9-benzylpurines, and their antimycobacterial activities. Compounds modified in the imidazole ring. Bioorg Med Chem. 2010;18:7274-7282.

30. Chaudhari PK, Pandey A, Shah VH. Synthesis and biological studies of 1,2,3,4-tetrahydro pyrimidine derivatives. Orient J Chem. 2010:26:1377.

31. Shmalenyuk ER, Kochetkov SN, Alexandrova LA. Novel inhibitors of Mycobacterium tuberculosis growth based on modified pyrimidine nucleosides and their analogues. Russ Chem Rev. 2013;82:896-915.

32. Doan TN, Tran DT. Synthesis, antioxidant and antimicrobial activities of a novel series of chalcones, pyrazolic chalcones, and allylic chalcones. Pharmacol Pharm. 2011;2:282-288

33. Jyothi MV, Prasad YR, Venkatesh P, Sureshreddy M. Synthesis and antimicrobial activity of some novel chalcones of 3-acetyl pyridine and their pyrimidine derivatives. Chem Sci Trans. 2012;1:716-722.

34. Rao NS, Kistareddy C, Balram B, Ram B. Synthesis and antibacterial activity of novel imidazo $[1,2-a]$ pyrimidine and imidazo $[1,2-a]$ pyridine chalcones derivatives. Pharm Chem. 2012:4:2408-2415.

35. Sato Y, He JX, Nagai H, Tani T, Akao T. Isoliquiritigenin, one of the antispasmodic principles of Glycyrrhiza ularensis roots, acts in the lower part of intestine. Biol Pharm Bull. 2007;30:145-149.

36. Patel VG, Goswami TK. Synthesis, spectral characterization and biological evaluation of some novel pyrazolines. J Chem Biol Phys Sci. 2014:4:3070.

37. Asiri AM, Marwani HM, Alamry KA, Al-Amoudi MS, Khan SA, El-Daly SA Green synthesis, characterization, photophysical and electrochemical properties of bis-chalcones. Int J Electrochem Sci. 2014;9:799-809.

38. Bakht MA, Ansari MJ. Synthesis of chalcone 1-(2,4-dihydroxyphenyl)-3(3-hydroxy-4-methoxyphenyl) prop-2-en-1-one via conventional and sonochemical methods: a comparative study. Int J Biol Pharm Appl Sci. 2014: 3:705-717. 
39. Balaji P, Ranganayakulu D, Ramyayadav K, Jayamma J, Reddykumar S, Sivaramaiah C. Anthelmintic and anti-microbial activities of synthesized heterocyclic pyrazole and its derivatives from fluoro substituted hydrazino benzothiazole. Int J PharmTech Res. 2014;6:1970-1975.

40. Daina A, Michielin O, Zoete V. SwissADME: a free web tool to evaluate pharmacokinetics, drug-likeness and medicinal chemistry friendliness of small molecules. Sci Rep. 2017;7:42717.

41. Daina A, Zoete V. A BOILED-EGG to predict gastrointestinal absorption and brain penetration of small molecules. ChemMedChem. 2016;11: 1117-1121.

42. Jones G, Willett P, Glen RC, Leach AR, Taylor R. Development and validation of a genetic algorithm for flexible docking. J Mol Biol. 1997:267:727-748.

43. Jones $G$, Willett $P$, Glen RC. Molecular recognition of receptor sites using a genetic algorithm with a description of desolvation. J Mol Biol. 1995;245:43-53.
44. Huang SY, Zou X. Ensemble docking of multiple protein structures: considering protein structural variations in molecular docking. Proteins. 2007;66:399-421.

45. Webb EF, Griswold DE. Microprocessor-assisted plethysmograph for the measurment of mouse paw volume. J Pharmacol Methods. 1984;12 149-153.

46. Palm K, Stenberg P, Luthman K, Artursson P. Polar molecular surface properties predict the intestinal absorption of drugs in humans. Pharm Res. 1997;14:568-571.

47. Verdonk ML, Cole JC, Hartshorn MJ, Murray CW, Taylor RD. Improved protein-ligand docking using GOLD. Proteins. 2003;52:609-623.

48. Adeniyi AA, Ajibade PA. Comparing the suitability of autodock, gold and glide for the docking and predicting the possible targets of Ru(II)-based complexes as anticancer agents. Molecules. 2013;18:3760-3778.

49. Suralkar AA, Sarda PS, Ghaisas MM, Thakare VN, Deshpande AD. In-vivo animal models for evaluation of anti-inflammatory activity. Latest Rev. 2008;6.

This work is licensed under a Creative Commons Attribution-NonCommercial 3.0 Unported License which allows users to read, copy, distribute and make derivative works for non-commercial purposes from the material, as long as the author of the original work is cited properly. 